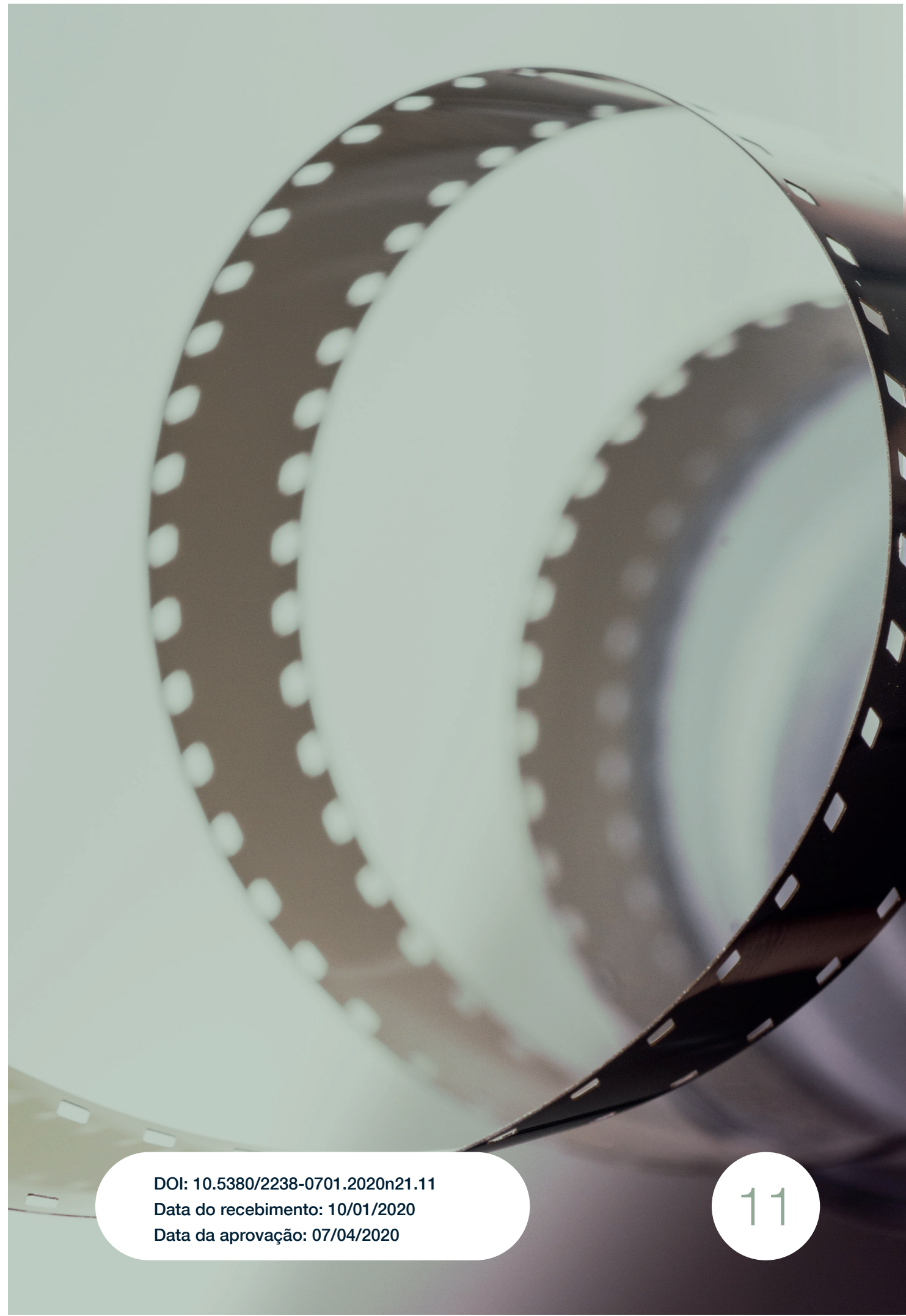


A narração no documentário direto brasileiro: usos e diferenças entre o "modelo sociológico" de 1964 e Martírio (Vincent Carelli, 2016) 


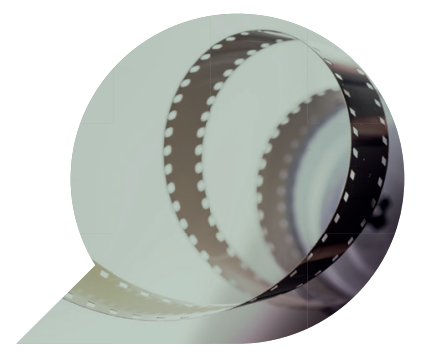

\section{A narração no documentário direto brasileiro: usos e diferenças entre 0 "modelo sociológico" de 1964 e Martírio (Vincent Carelli, 2016)}

The narration in the Brazilian documentar: uses and diferences between the 1964 "sociological model" and Martírio (Vincent Carelli, 2016)

La narración em el documental brasileño: usos y diferencias entre el "modelo sociológico" de 1964 y Martírio (Vincent Carelli, 2016)

CARLOS EDUARDO RIBEIRO'

Resumo: $\mathrm{O}$ artigo consiste em uma análise comparativa do uso da narração em voz over em documentários de estilo direto dentre dois contextos de realização distintos no Brasil, que são a década de 1960 e os tempos recentes. Os filmes abordados são Viramundo (Geraldo Sarno, 1964), Maioria Absoluta (Leon Hirszman, 1964) - representativos das primeiras investidas do direto no Brasil e do que Jean-Claude Bernardet (1985) define como "modelo sociológico" - e, em outro momento, Martírio (2016), parte do projeto Vídeo nas Aldeias. Em uma análise, buscamos sondar por semelhanças e rupturas nas formas de falar sobre o Outro

1 Doutorando em Comunicação na Universidade Federal do Rio grande do Sul. Mestre em Sociologia pela Universidade Federal de Pelotas. Assistente de Pesquisa na Universidade do Vale do Rio dos Sinos. 
nesses filmes, nas formas de construção de verdade por parte dos documentaristas, e indagar como a voz do narrador é articulada à voz dos sujeitos documentados; possivelmente nos levando a inferências sobre a transformação na forma do uso da voz over em documentários militantes brasileiros de estilo direto.

Palavras-chave: Documentário brasileiro; Voz over; Martírio (Vincent Carelli, 2016); Viramundo (Geraldo Sarno, 1964); Maioria Absoluta (1964).

Abstract: The article consists of a comparative analysis of the use of voice-over narration in documentaries between two distinct realization contexts in Brazil, which are the 1960s and recent times. The films addressed are Viramundo (Geraldo Sarno, 1964), Maioria Absoluta (Leon Hirszman, 1964) - representative of what Jean-Claude Bernardet (1985) defines as a "sociological model" and, on the other hand, Martírio (2016), part of the project Vídeo nas Aldeias. The analysis seeks to probe for similarities and ruptures in the ways of talking about the Other in these films, in the forms of truth construction by documentarists and to inquire how the voice of the narrator is articulated with the voice of the documented subjects; possibly leading us to inferences about transformations in the forms of Brazilian militant direct documentaries.

Keywords: Brazilian documentary; Voice over; Martyrdom (Vincent Carelli, 2016); Viramundo (Geraldo Sarno, 1964); Absolute Majority (1964).

Resumen: El artículo consiste en un análisis comparativo del uso de la narración em off en documentales entre dos contextos de realizción distintos em Brasil, que son los años sesenta y los últimos tiempos. Las películas abordadas son Viramundo (Geraldo Sarno, 1964), Maioria Absoluta (Leon Hirszman, 1964) - representantes de lo que Jean-Claude Bernardet (1985) define como um "modelo sociológico" - y, por outro lado, Martírio (2016), parte del proyecto Vídeo nas Aldeias. El análisis busca investigar las similitudes y rupturas en las formas de hablar del Otro en estas películas, en las formas de construcción de la verdad por parte 
de los documentalistas, y preguntar cómo se articula la voz del narrador con la voz de los sujetos documentados; posiblemente llevándonos a inferencias sobre la transformación en forma de documentales militantes brasileños.

Palabras clave: Documental brasileño; Voz en off; Martirio (Vincent Carelli, 2016); Martírio (Vincent Carelli, 2016); Viramundo (Geraldo Sarno, 1964); Maioria Absoluta (1964).

\section{Introdução}

O artigo consiste em uma análise comparativa entre dois contextos de realização de documentário direto no Brasil. O primeiro contexto, analisado através dos curtas-metragens Viramundo (Geraldo Sarno, 1964) e Maioria Absoluta (Leon Hirszman, 1964), aborda estes que são lembrados como os primeiros documentários brasileiros com entrevista (GUIMARÃES, 2008, p.16), parte das primeiras experiências brasileiras com o cinema direto, e os mais representativos do que Jean-Claude Bernardet (1985) chamou de "modelo sociológico". O "estilo direto", em certa medida semelhante à reportagem (RAMOS, 2008, p. 59), é correlato à introdução de equipamentos de captação portáteis, então inovadores. Refiro-me ao Nagra III, gravador com a portabilidade de uma maleta inventado pelo polonês Stefan Kudelski na Suíça em 1958. Concebido para o uso telejornalístico, globalmente tomou parte da prática do cinema direto e do cinema verdade, tornando-se o principal equipamento portátil para a gravação. O Itamaraty e a Unesco promoveram no Brasil, em 1962, um curso com o documentarista sueco Arne Sucksdorf que ajudou a difundir a técnica do direto naquela geração de documentaristas, dentre os quais Leon Hirszman e Geraldo Sarno, diretores dos filmes aqui analisados (FIDELIS e MARQUES, 2016, p. 10-11; GUIMARÃES, 2008; PORTO, 2019, RAMOS, 2008, p. 341-2). O estilo direto, teorizado e praticado transnacionalmente à época ${ }^{2}$, tratou-se de um momento-cha-

\footnotetext{
2 À despeito de que os autores brasileiros da época referiam prioritariamente a "cinema verdade" em detrimento de "cinema direto" (RAMOS, 2008, p.288), ao preferir falar em "direto" me refiro à nova estilística documentária e sua tecnologia. Quanto à discussão entre as distinções e simetrias entre as designações "verdade" e "direto", interessa que essa distinção originária, após a primeira metade da década de 1960, perde sentido significativamente (RAMOS, 2008, p. 270).
} 
ve de reviravolta estilística que influenciou o cinema brasileiro da época como um todo (RAMOS, 2008, p. 269), permitindo aos documentaristas deslocarem-se ao encontro das vozes do "povo".

Já Martírio é um filme de 2016, dirigido pelo antropólogo indigenista Vincent Carelli, um parisiense naturalizado brasileiro. A narrativa do longa-metragem foca o quotidiano e a diáspora dos Guarani Kaiowá, especialmente a luta desse povo pela retomada de seus territórios sagrados, compreendendo materiais desde 1986 até 2015. De maneira adjunta a essas imagens-câmera, montam-se imagens de arquivo que remetem a um passado mais longínquo, que busca dar conta da história do Mato Grosso do Sul - onde se passa o filme - e da relação histórica entre o Estado brasileiro e os povos indígenas. Vemos, ao longo das duas horas e meia de filme, imagens que remetem à Guerra do Paraguai, ao SPI e Marechal Rondon, a Getúlio Vargas, ao fim da ditadura civil-militar, à bancada ruralista; todas comentadas pelo documentarista-narrador Vincent Carelli.

A asserção em voz over é uma marca do documentário enquanto gênero cinematográfico, em muitos casos o recurso de comunicação mais direto entre cineasta e público no interior do filme. Ao abordar o uso da narração nesses filmes, que entremeiam narração e estilo direto, busco compreender como nesses distintos contextos se propõem leituras sobre o mundo social, identificando, a partir do uso da narração/locução/voz over - também comumente chamada "voz de Deus" ou "voz do saber" (GUIMARÃES, 2008, p.14) -, diferenças nas abordagens construídas por esses documentários. Na análise da narração nesses filmes engendrada ao longo do texto, encontram-se de maneira diluída as seguintes questões norteadoras: como em cada vertente e filme a voz over é mobilizada para interpretação do mundo e construção de verdade por parte dos cineastas? Como a voz do narrador partilha o espaço e verdade do documentário com as vozes dos demais sujeitos no filme? Que espaço deixa para o acaso e para a heterogeneidade de vozes, de presenças, ação e pensamento? Há mudanças no emprego da narração ao longo das décadas? Essas mudanças podem nos dizer algo sobre as formas de fazer documentário militante e direto no Brasil recente? 


\section{Metodologia}

Considerando a impossibilidade de um método de investigação acabado em termos de análise fílmica (AUMONT e MARIE, 2011; JULLIER e MARIE, 2009) uma vez que o processo envolve objetos e objetivos dos mais variados, posições subjetivas por parte dos investigadores, uma pluralidade de escolas dedicada aos estudos de/em cinema e uma gama heterogênea de obras; e considerando que a bibliografia à disposição acerca desse tipo de análise aponta para a necessidade de construção de um método ao longo do processo de pesquisa; analisarei trechos e características gerais de cada um dos filmes, pré-selecionados a partir de sua relevância para o problema elencado. De maneira adjunta à técnica da análise fílmica, lanço mão de revisões bibliográficas sobre o documentário, sobre suas características no Brasil nas épocas que compõem o corpus da pesquisa, bem como sobre as temáticas sociológicas e perspectivas epistemológicas em voga em cada contexto. Considero metodologicamente, de uma perspectiva textual e contextual, que o contexto é simultaneamente a condição de possibilidade de existência das obras audiovisuais e evocado em seu interior, de forma que os filmes emergem do e remetem ao meio social circundante. A organização simbólica interna de cada obra audiovisual, contextual e simultaneamente subjetiva por parte do realizador, extrapola o seu controle, ao passo em que é arranjada por ele nessa linguagem de codificação lacunar e complexa que é o cinema. A narração, tanto quanto outros elementos narrativos, indica a atitude e a individualidade dos cineastas diante do mundo e do outro a serem representados. Considerando o interior do filme um espaço onde uma série de vozes fundem-se e entram em conflito, busco estabelecer um diálogo entre elementos internos (imagem e som) e externos (epistemologias, tecnologias e conflitos sociais) dos filmes, bem como entre ambas as vertentes de realização elegidas, verificando a possibilidade de inferências sobre as formas e transformações desses documentários que aqui chamo de "militantes" e "diretos". 


\section{Viramundo e Maioria Absoluta}

A obra de diversos artistas e intelectuais do Brasil da década de 1960 foi marcada por certo fervor político e ímpeto nacionalista, o que o historiador Marcelo Ridenti (2005), fazendo uma apropriação criativa do conceito de "estrutura de sentimento" de Raymond Williams ${ }^{3}$, apontou como "estrutura de sentimento da brasilidade romântico-revolucionária": uma resposta às mudanças na realidade social da época, um fenômeno vasto, que permeia obras e formas de pensar sem que necessariamente os agentes percebam-na no momento em que a constituem. Esse sentimento romântico-revolucionário marcou fortemente o CPC, "talvez o mais importante interlocutor do Cinema Novo" (SIMONARD, 2006, p. 84), cuja meta era "utilizar elementos da cultura popular para desalienar o povo", (idem., p. 26); bem como o ISEB (Instituto Superior de Estudos Brasileiros), a UNE (União Nacional dos Estudantes) e cineastas cariocas e paulistas da época. Nesse contexto, especificamente em 1964, são realizados os documentários Viramundo e Maioria Absoluta, alguns dos primeiros filmes de estilo direto no Brasil, e que tomam parte na constituição da linguagem da fase dita "moderna" no documentário brasileiro, a qual viveu "os debates em torno do nacional-popular e da problemática do realismo" (XAVIER, 2001, p.15).

$\mathrm{Na}$ intersecção entre essa estrutura de sentimento definida por Marcelo Ridenti, entre inovações tecnológicas que permitiam maior mobilidade às equipes de filmagem, e apropriações das experiências do cinema direto e do neorrealismo italiano, curtas-metragens à época fizeram excursões a favelas, aos sertões nordestinos onde se corta cana, a quilombos ou às lutas campesinas; propondo, na expressão de Ismail Xavier (2001, p. 27), uma "descoberta do Brasil" vista a escassez de imagens de certas regiões do país na época.

Se o cinema direto foi inicialmente marcado pelo "recuo do cineasta em seu corpo-a-corpo com o mundo" (RAMOS, 2008, p. 270), essa "ética da imparcialidade" (Idem., p.36), na forma com que foi apropriada em Viramundo e Maioria Absoluta, carrega consigo um caráter interpretativo, fortemente marcado nos usos da narração. Robert Drew, cineasta e teórico pai do cinema direto, já vivenciava as ambiguidades desse

3 Ligada às práticas sociais e aos hábitos mentais de uma época, é a expressão do "pensamento tal como sentido e do sentimento tal como pensado" (Williams, 1979, p. 135 apud RIDENTI, 2005, p. 82). 
recurso: embora teorizasse sobre a abolição do narrador em seus filmes, buscando um distanciamento radical do documentário clássico educativo-cientificista, não conseguiu fazê-lo. Se o som sincrônico na tomada é talvez o procedimento predominante desse novo aparato tecnológico, muitas vezes, especialmente no Brasil, fez-se uso da voz over tradicional (idem., p.280). Michel Chion, teórico do som no cinema, aponta como essa arte é verbocêntrica: "quando existe a voz no cinema todos os sons se submetem à sua hierarquia" (apud GUIMARÃES, 2008, p.15). No caso dos dois curtas metragens brasileiros, o deslocamento físico dos cineastas, de teor etnográfico, acompanha uma narração de cunho sociológico, que busca explicar o Brasil a partir das experiências dos sujeitos lesados ou esquecidos no processo modernizador. A interpretação marcada pelas narrações coloca o impasse entre objetividade e subjetividade no papel dos realizadores; entre a verdade do diretor e a intenção de dar voz ao povo. O saber científico do cineasta não parte da experiência, mas, justamente, depende da "exterioridade do locutor em relação à experiência” (BERNARDET, 1985, p.14),

já que quem vivencia a experiência só consegue falar de sua superfície. Os migrantes, de que os entrevistados são a amostragem, são o objeto da fala do locutor, que se constitui em sujeito detentor do saber. Sua participação na experiência seria a própria negação de seu saber, já que dentro da experiência só se obtém dados individuais, parciais, fragmentados.

Guilherme da Rosa (2012, p.25) identifica nesses filmes a

postulação de uma única verdade sobre um determinado contexto (...) e de um exercício de alteridade que põe o cineasta/diretor/ cientista social como alguém plenamente capaz de dar conta desta verdade que não pode pertencer, de maneira alguma, aos atores sociais do documentário.

A intenção de objetividade desses cineastas, correlata à técnica e teoria do cinema direto, mescla-se a um norte político, herdeiro do neorrealismo e especialmente da estrutura de sentimento da brasilidade romântico-revolucionária. Nas palavras de Marcelo Ridenti (2005, p. 87), essas obras "revelam a emoção e a solidariedade dos autores com o sofrimento do próximo, a denúncia das condições de vida subumanas nas grandes cidades e, sobretudo, no campo", dando especial atenção ao "drama dos retirantes nordestinos", como é o caso de Viramundo. O 
tema do curta-metragem é o "contingente nordestino da classe operária paulista (classe operária que é a principal do país e cujo contingente nordestino é extremamente elevado)" (BERNARDET, 1985, p. 27); em outras palavras, os nordestinos que diariamente migram para São Paulo, nesse contexto de "um dos processos de urbanização mais rápidos da história mundial: de 1950 a 1970, a sociedade brasileira passou de majoritariamente rural para eminentemente urbana" (RIDENTI, 2005, p. 87). A narração e a montagem do filme sugerem que a amostragem de migrantes experimenta dificuldades na aderência à racionalidade urbana, o que o filme explica a partir do seu excesso de religiosidade, tida como uma lógica tradicional e irracional. O filme aposta na tensão entre o que chama de formas socioeconômicas "atrasadas" ou "tradicionais" do sertão nordestino e, por outro lado, a forma "urbana" da capital paulista em expansão. Viramundo é, segundo Jean-Claude Bernardet, emblemático marco do "modelo sociológico" dos documentários da época. A aproximação da perspectiva dos cineastas com um olhar científico, que por si se difere das falas e saberes dos sujeitos pelos quais o filme se interessa, fica patente na primeira cartela de títulos do filme: "as pesquisas realizadas para a elaboração do argumento deste filme foram orientadas pelos professores Octavio lanni, Juarez Brandão Lopes e Cândido Procópio".

O contingente de migrantes entrevistados, centenas que chegavam diariamente a São Paulo segundo a narração, conforme os depoimentos viajava em busca de trabalho e melhores condições de vida, mas acabava em geral empregado como mão de obra não qualificada na construção civil, indústria ou então desempregado. No terceiro ato do curta-metragem, esse personagem/classe é representado em rituais de candomblé, nas igrejas católicas, centros espíritas ou em uma sessão dominical de culto protestante que ocupa toda a extensão de uma praça pública num domingo. No clímax do filme, seus corpos recebem entidades ou entram em transes. Enfim, conforme o filme se aproxima do final, os nordestinos vão embora da capital onde permanece a câmera, usando-se da mesma estação de trem por onde chegaram; e simbolicamente reiterando sua diferença com os cineastas paulistas. Essa indagação sobre religião e racionalidade emerge, segundo Jean-Claude Bernardet (1985, p.27), de "uma pergunta latente: por que o golpe de Estado de 31 de março de 1964 ocorreu sem resistência popular significativa (...) O filme responde: eis a situação da classe operária (...) Ela não tem como 
se afirmar, se mobilizar, só se resolve na alienação".

Como resposta à alienação do povo, e fazendo coro à busca romântico-revolucionária por uma arte nacional-popular que colaborasse com a desalienação das consciências (RIDENTI, 2005, p.87), no curta-metragem de Geraldo Sarno, o narrador onisciente busca quebrar as possíveis ambiguidades interpretativas para o público, costurando linearmente e racionalmente as imagens apresentadas pela montagem. Já apontou Mary Ann Doane que o poder da narração "está na possessão do conhecimento e na privilegiada, inquestionável, atividade de interpretação" (DOANE, 1983, p.467). O narrador de Viramundo, cujo rosto não se vê, por vezes dirige perguntas a um auxiliar de locução, chamado apenas Sr. Empresário, que vemos em seu escritório respondendo em vocabulário técnico. Os migrantes, diferentes do empresário, não falam de maneira erudita e parecem ter como expressão mais marcante o transe. $\mathrm{O}$ recurso a esse narrador intermediário acaba por salientar a distância entre o próprio público e os migrantes: a montagem dá ao espectador mais proximidade com o Sr. Empresário, que tem nome, que recorre mais frequentemente na tela que cada migrante, que se apresenta menos tenso à câmera. Os migrantes não são nomeados e são mostrados majoritariamente em grupos numerosos, sobre os quais a voz over diz coisas que eles não sabem a seu próprio respeito.

Essa diferença de posição social construída entre cineastas e povo, entre público e povo, e entre os locutores e o povo, coaduna com diferentes posições de enunciação dentro do filme e com diferenças no tratamento estético das faixas de áudio: a voz over do cineasta, gravada em estúdio, limpa de ruídos, planejada e sugerindo intimidade; a voz do Sr. Empresário, ocupando um lugar intermediário, gravada em ambiente interno, com relativa clareza e planejamento, com um vocabulário culto, profissional e urbano; as vozes captadas na rua, que figuram, nesse esquema comparativo, como as mais sujas e espontâneas, sugerindo realismo. As vozes dos analfabetos e migrantes são interpostas pela confusão cotidiana, pelo barulho das feiras e rodoviárias, pelo quotidiano que irrompe pelas paredes finas de suas casas. Uma quarta categoria na orquestração dessas vozes é possível: trata-se da trilha sonora, a canção "Viramundo" interpretada por Gilberto Gil, cantor que, ainda que vindo do Nordeste - ou seja, em semelhança com os trabalhadores representados no filme -, vivia em condições muito diversas das sujeitos cujos 
rostos são apresentados, tanto no que toca à forma de trabalho quanto à apreensão de capitais culturais e econômicos. Sua fala tem cada frase metodicamente planejada e entonada, usufruindo da preparação típica da composição musical, em oposição à espontaneidade conferida aos sujeitos do filme. A voz do artista, poetizando o drama desse contingente populacional sobre o qual fala, é captada em ambiente controlado, como se espera de uma trilha musical.

Maioria Absoluta, curta-metragem da mesma época, perfaz, com Viramundo, um exemplo do "modelo sociológico" nas palavras de Jean-Claude Bernardet (1985); embora obra de cineastas cariocas e não paulistas. O filme aborda o analfabetismo, especialmente os cortadores de cana no interior de Pernambuco a quem era negado o direito ao voto. Conforme os próprios testemunhos, trabalhavam sob chuva ou sol e nunca haviam visto uma câmera, muitos sequer tocado em dinheiro. A partir das imagens de seus corpos e roupas podemos imaginar a insalubridade da vida que levam, em condições de semiescravidão. A narrativa denuncia a amplitude do analfabetismo e o relaciona com a fome e a tradicional exploração do coronelismo nordestino. Há no filme uma cena onde vemos os rostos desses caboclos em uma pausa do trabalho, enquanto a locução explica que os analfabetos perfazem 2/3 da população brasileira, sugerindo e justificando ser esse o rosto do povo. O problema brasileiro é explicado, no filme de Hirszman, a partir da má distribuição de oportunidades e recursos, a serem corrigidas por um projeto modernizador adequado. Esse filme também lança mão de um "informante intermediário" tal como o Sr. Empresário em Viramundo: trata-se aqui de Darcy Ribeiro, sociólogo que faz asserções sobre o povo brasileiro. Diferente do saber especialista de Darcy Ribeiro, conforme Bernardet (1985, p. 12), os sujeitos do filme são "a voz da experiência (...) Falam só de suas vivências, nunca generalizam, nunca tiram conclusões. Ou porque não sabem, ou porque não querem, ou porque nada lhes é perguntado nesse sentido.", de forma que o modelo sociológico "não permite que os sujeitos do documentário tenham acesso a suas verdades" (ROSA, 2012, p. 27). É particularmente representativo desse efeito o momento do filme em que o narrador promete "passar a voz aos analfabetos": vemos na imagem um campesino, em aparente situação de precariedade material, que treme e gagueja patologicamente. A ligação entre imagem e som dá a entender que os analfabetos não podem falar, devem ser 
explicados. Ouvimos então o depoimento da esposa desse campesino, explicando sua doença, oriunda do trabalho exaustivo com a cana.

Essa contradição "entre a forma estilística do direto, explorando a nova tecnologia que permite abrir a tomada na indeterminação, e a necessidade de um didatismo social, que vê o documentário como elo transmissor de uma missão educativa" (RAMOS, 2008, p. 331), trata-se, nas palavras do autor, da "contradição que caracteriza o coração da estilística do direto no Brasil” (idem., p. 330). A expressão mais radical dessa contradição, situada no que Bernardet chamou de "modelo sociológico", coaduna em uma "tese da alienação" (BERNARDET, 1985): a ideia de que o povo é incapaz de falar por si, o menosprezo por seus saberes e práticas sociais, ainda que dignos de certo interesse paternalista a partir do olhar dos cineastas.

\section{Martírio}

Um contraponto interessante ao "modelo sociológico" empregado em Viramundo e Maioria Absoluta é a produção do Vídeo nas Aldeias, do antropólogo Vincent Carelli, projeto iniciado em 1984 e consolidado como ONG em 2000, existente até hoje. O projeto foi um dos primeiros encontros entre povos tradicionais e audiovisual no Brasil, atuando atualmente em dezenas de comunidades, o que vem resultando em algumas dezenas de filmes entre curtas e longas-metragens. Esses filmes têm temáticas plurais: o quotidiano da aldeia, os mitos, os jovens, as particularidades locais e de cada povo, as relações com os brancos, etc. As perspectivas, embora oriundas de indígenas, também são diversas: em parte, pela heterogeneidade desses povos que reunimos sob o guarda-chuva "indígena", e, mais especificamente, pela pluralidade de subjetividades, subjetivações e experiências que cada povo comporta. A ONG, que começou como cursos voltados ao ensino da prática cinematográfica para indígenas, está em afinidade e contemporaneidade global com uma série de outras iniciativas que possibilitam aos povos originários realizarem cinema.

Esse tipo de produção e narrativa é altamente correlata às novas possibilidades do período pós-redemocratização. Conforme Ismail Xavier (2001, p. 38), a cinematografia brasileira vem sendo, desde a 
década de 1990, marcada pela afluência e legitimação de uma maior gama de enquadramentos discursivos e uma maior diversificação das equipes realizadoras em atuação. Essa democratização da realização, que passa por influências políticas e econômicas do período, está ligada também ao advento e democratização das tecnologias digitais para audiovisual ${ }^{4}$ no mesmo período. $O$ advento do vídeo figura no nome do projeto - Vídeo nas aldeias -, que abre mão da designação mais clássica de cinema (que é classicamente ligada à película e às tecnologias analógicas).

O documentário que analiso dessa ONG é Martírio, ambientado no Mato Grosso do Sul, dirigido pelo próprio Vincent Carelli. O longa-metragem foi inicialmente financiado com $\mathrm{R} \$ 85.000$ provenientes de um crowdfunding com a colaboração de mais de 1.000 pessoas, e finalizado com incentivo do Funcultura do Estado de Pernambuco. A base do material de Martírio são as vivências e filmagens do antropólogo/diretor com os Guarani e Kaiowá desde 1984, através das quais o filme expõe a violação das terras e vidas desse povo ora para a plantação de erva-mate, ora de soja; buscando atestar o desinteresse do Estado brasileiro e do agronegócio em reconhecer e fazer valer os direitos indígenas. Trata-se de um filme didático, em certa afinidade com o documentário clássico e com as primeiras experiências do cinema direto no Brasil. A pouca invenção formal do longa-metragem, que leva adiante o casamento entre estilo direto e caráter pedagógico, foi notada pela crítica, ao passo em que a atualidade do tema explorado e sua relevância sócio-política despertaram atenção. O filme estreou em 2016 no 49 Festival de Brasília de Cinema Brasileiro, onde foi aplaudido por mais de cinco minutos após a exibição e venceu o Prémio do Júri Popular e o Prêmio Especial do Júri. Martírio "(...) recebeu [do público] uma consagração como havia muito não se assistia no Cine Brasília", constatou o crítico de cinema Luis Oricchio (ORICCHIO, 2016). Foi apontado pela Associação Brasileira de Críticos de Cinema (Abraccine) como o melhor longa-metragem brasileiro exibido em circuito comercial no ano de 2017, além de

4 Marcelo Ikeda já apontou as possibilidades oriundas do digital, tanto para uma produção mais ágil, barata e flexível quanto para uma difusão mais horizontal. "Ou seja, além de permitir a realização de obras sem a necessidade de estruturar um projeto para participar de editais públicos, o vídeo permitiu que os filmes pudessem ser produzidos mediante um outro arranjo de produção." (IKEDA, 2014, s/p). Ademais, ao tentar caracterizar o cenário contemporâneo do cinema brasileiro, o pesquisador aponta que "uma das características dessa nova geração é a forte presença do documentário" (Idem.), escopo no qual se insere o filme que comentamos. 
ter rendido elogios e homenagens em mídias e festivais diversos.

Martírio busca dar a ver a história dos Guarani Kaiowá desde antes da república, com especial foco na recente retomada de seus territórios sagrados. De maneira adjunta às imagens feitas nos territórios ocupados visitados por Carelli, vemos imagens de arquivo diversas, dentre as quais algumas remontam à criação do SPI (Serviço de Proteção aos Índios), em 1910, coordenado pelo Marechal Rondon, o qual Carelli define em sua narração como "militar positivista" que "vem pacificar as relações com as populações indígenas para permitir a colonização da fronteira Oeste do País". Carelli afirma, sobre as imagens de arquivo que monta, que "O SPI nomeava capitães afinados com o seu projeto de assimilação cultural", afastando os índios de seus costumes. "A missão do SPI era inseri-los na incontornável marcha da humanidade pelo progresso". De maneira correlata a essa relação entre povos indígenas e Estado no passado, vemos em outras sequências os rumos desse tipo de política institucional hoje, especialmente através da discussão da Proposta de Emenda Constitucional 215 (da autoria do deputado gaúcho do PP Luiz Carlos Heinze, chancelada por Eduardo Cunha) que, pouco antes do Impeachment de Dilma Rousseff (o filme é lançado antes desse acontecimento), freia a demarcação de territórios indígenas. Durante essa votação, um deputado brasileiro exclama convicto: "terra pra índio, nem por cima do meu cadáver!". Vemos, pelo olhar lançado por Carelli, o crescente poder do "lobby ruralista", nas palavras do narrador. A essa sequência se intercalam imagens do desespero das famílias Guarani Kaiowá no mato Grosso do Sul frente ao quotidiano risco de morte, às ameaças corriqueiras a adultos e crianças, ao envenenamento de sua água e comida.

As sincronias com o momento da década de 1964 não se limitam a uma confluência entre o estilo direto e certo didatismo: também o diretor não é um indígena, como em Viramundo o diretor não era um migrante nordestino, e em Maioria Absoluta a equipe de filmagem não era cortadora de cana; restando uma diferença de posição social em todos esses filmes entre cineastas e sujeitos representados. Por outro lado, se nos filmes que analisamos da década de 1964 a voz over não se anuncia como sujeito localizado - aderindo à pecha de "voz de Deus" -, Carelli narra como "eu". Outros pesquisadores já vêm notando que recorre no documentário recente a enunciação em primeira pessoa (RENOV, 2004; 
RASCAROLI, 2009), quando o documentarista deixa de mediar o filme dos bastidores e passa a ocupar a cena, misturando-a explicitamente às suas inquietações pessoais. Vincent Carelli conduz o filme com seu corpo e voz. A diferença mais flagrante com Viramundo é que Carelli filia-se à perspectiva política indígena, não é exógena a ela, mas produto de um processo de escuta gestado ao longo dos trinta anos em que esteve em contato com os Guarani Kaiowá. Esse recorte de tempo, diferente do imediatismo e ineditismo das primeiras experiências do direto, permite um maior distanciamento entre o cineasta e o material. Em outras palavras, ao passo em que o didatismo empregue nas cenas em que fala sobre a história dos povos indígenas aproxima a forma do seu filme de Viramundo e Maioria Absoluta, a enunciação engendrada em primeira pessoa pelo antropólogo inclui amplamente sua voz e corporalidade, de forma que, ainda que seja um francês naturalizado brasileiro, a partir da "experiência" (SCOTT, 1998), aprende formas mais sutis de captar e compartilhar da perspectiva dos indígenas se em comparação com os documentaristas sessentistas, para quem os entrevistados eram recém conhecidos.

A relação pessoal estabelecida por Carelli com seu "objeto" transparece durante os registros dos momentos mais tensos do documentário, quando captamos suas emoções na entonação da locução, quando chora, quando participa de rituais sagrados, quando coloca seu corpo em risco pelas filmagens. A implicação de Carelli no filme aparece também na montagem: a transição entre as sequências dos filmes é feita por imagens gravadas pela janela de um carro em movimento na estrada, através da qual vemos lotes agrícolas no Mato Grosso do Sul. O narrador divaga sobre essas imagens, como se compartilhasse conosco seus pensamentos enquanto dirige. A trajetória do filme parece buscar coadunar à trajetória do diretor dentre o conflito. Se por um lado o filme adere à sua perspectiva de uma forma altamente pessoalizada, por outro, a maneira com que Carelli acompanha a trajetória e luta indígena concede a eles certo protagonismo na condução do documentário, no sentido em que o cineasta adere à sua perspectiva política.

A presença em primeira pessoa, da maneira que é articulada, opera no sentido de buscar um menor distanciamento e maior experiência compartilhada entre documentarista e sujeitos do documentário. Dessa perspectiva, ao passo em que há uma diferença de "origem" ou de "po- 
sição social" em todos os filmes analisados no que toca à relação entre documentaristas e sujeitos representados, a perspectiva empregue em Martírio faz flagrantes nortes epistemológicos diferentes dos empregados nos filmes de 1964; ou seja, ao passo em que se conserva uma relação de "alteridade", o exercício em primeira pessoa do antropólogo do Vídeo nas Aldeias, ao não mirar a "neutralidade" cientificista dos filmes analisados da década de 1960, inclui mais diretamente e horizontalmente o encontro que se tece no entorno da gravação.

\section{Considerações finais}

São identificáveis semelhanças que afinam o modelo sociológico sessentista do tipo de enunciação engendrada por Carelli: a diferença de posição social entre cineastas e sujeitos do filme, a diferença de posição de enunciação entre ambos no interior do filme - salientada pelo uso da narração, que sublinha a perspectiva e o saber do cineasta -, o estilo direto que concede espaço à voz over pedagógica da equipe realizadora. Essas características, contudo, não conformam por si perspectivas análogas. As abordagens do mundo pelos cineastas, construídas particularmente em cada filme e cada contexto, em suas diferenças, demonstra diferentes usos dos recursos do documentário, ao passo em que se relacionam a "estruturas de sentimento" (WILLIAMS, 1979), tecnologias e nortes epistemológicos em voga em cada contexto.

A mudança nas tecnologias audiovisuais, que redunda na migração da película para o digital, permite no contemporâneo uma maior acessibilidade e praticidade no processo de fazer cinema. Essa mudança encaminha o descentramento das perspectivas possíveis no cinema, a maior pluralidade de equipes realizadoras e locais de realização, o menor custo envolvido, a independência em relação aos grandes centros urbanos que outrora já foram os únicos a finalizar e reproduzir as películas. Para além desse caráter técnico-econômico, se o problema sociológico dominante no Brasil da década de 1960 foi o desenvolvimentismo e o terceiro-mundismo, hoje parece ser a pluralidade, a efetivação das políticas democráticas implementadas. Assim, o norte marxista e objetivista dos documentários sessentistas tratou por vezes os sujeitos documentados como "amostragem" de pesquisa, como classe de indivíduos sem 
nome. Essa epistemologia delineia a própria temática dos filmes e fala também sobre sua forma: se no desenvolvimentismo era central o papel do intelectual que explicaria a economia e geopolítica aos camponeses analfabetos e aos nordestinos de hábitos tradicionais, o paradigma contemporâneo nas ciências sociais aponta para o dialógico, para a valorização dos saberes e vozes subalternos. Os rumos do documentário contemporâneo evidenciam as reflexões sobre as formas de partilha entre cineastas e sujeitos representados, tendo colocado exaustivamente em xeque o paradigma anterior.

Em um trabalho de maior fôlego caberia ainda uma análise do tratamento dado dentro dos filmes àqueles que figuram como o "inimigo": a cínica classe média nas primeiras imagens de Maioria Absoluta, os ruralistas e sua bancada em Martírio. 


\section{REFERÊNCIAS}

AUMONT, Jacques; MARIE, Michel. A análise do filme. Texto \& Grafia: Lisboa, 2011.

BERNARDET, Jean-Claude. Cineastas e Imagens do Povo. São Paulo, Editora Brasiliense. 1985.

DOANE, Mary Ann. A Voz no cinema: a articulação de corpo e espaço. In: XAVIER, Ismail (Org.). A Experiência do cinema. Rio de Janeiro: Edições Graal: Embrafilme, 1983.

FIDELIS, Cid Nogueira; MARQUES, Márcia Gomes. O indígena no cinema documental. III Encontro Centro-Oeste de História da Mídia. ALCAR - Associação Brasileira de Pesquisadores de História da Mídia/Centro-oeste. UFMS. Junho de 2016.

GUIMARÃES, C. B. A introdução do som direto no cinema documentário brasileiro na década de 1960. 182 f. 2008. Dissertação (Mestrado em Estudos dos Meios e da Produção Mediática). ECA, USP, SP.

IKEDA, Marcelo. O "novíssimo cinema brasileiro": sinais de uma renovação ". Cinémas d'Amérique latine [Online], 18 de abr. de 2014. Disponível em: <http://journals.openedition.org/cinelatino/597>. Acesso em 8/12/2019.

JULLIER, Laurent \& MARIE, Michel. Lendo as imagens do cinema. São Paulo: Editora Senac São Paulo, 2009.

ORICCHIO, José Luiz. Filme conta a trágica saga dos guarani-kaiowá no Brasil. Exame, 24 de set. de 2016. Disponível em: <https://abr.ai/2Mmhl7s>. Acesso em 01/12/19.

PORTO, Igor Araújo. Interações entre técnica e estética: aproximações para o estudo do som direto em externas no Brasil. 42 Congresso Brasileiro de Ciências da Comunicação, Belém, 2019. São Paulo: Intercom, 2019. Disponível em: <http://portalintercom.org.br/anais/nacional2019>. Acesso em: 08/12/2019.

RAMOS, Fernão Pessoal. Mas afinal... o que é mesmo documentário? São Paulo: Editora Senac. 2008.

RASCAROLI, Laura. The personal camera: subjective cinema and the essay film. Nova lorque: Columbia University, Wallflower Press, 2009.

RENOV, Michael. The subject of documentary. Minneapolis: University of Minnesota Press, 2004.

RIDENTI, Marcelo. Artistas e intelectuais no Brasil pós-1960. Tempo Social: revista de sociologia da USP, v. 17, n. 1. 2005, p. 81-110.

ROSA, Guilherme. Viramundo e a relação entre sujeito e verdade no documentário brasileiro moderno.

Revista Orson. Online, 2012. no 3, p. 20-29.

SCOTT, Joan W. A invisibilidade da Experiência. Projeto História. São Paulo, 1998, p. 297-325.

SIMONARD, Pedro. A geração do Cinema Novo: para uma antropologia do cinema. Rio de Janeiro: Mauad X. 2006.

WILLIAMS, Raymond. Marxismo e literatura. Rio de Janeiro, Zahar. 1979. 
XAVIER, Ismail. O cinema brasileiro moderno. 3a ed. São Paulo: Paz e Terra. 2001.

Data do recebimento: 10 janeiro 2020

Data da aprovação: 07 abril 2020 


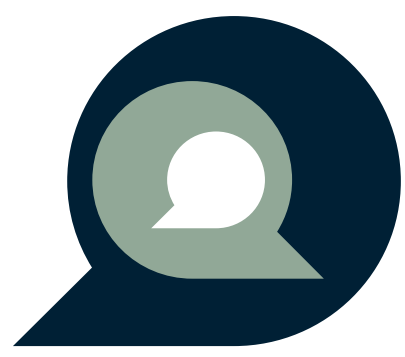

